\title{
Conditioned taste aversions: A bibliography
}

\author{
ANTHONY L. RILEY and LINDA L. BARIL \\ Dalhousie University, Halifax, Novia Scotia, Canada BSH $4 \mathrm{J1}$
}

\begin{abstract}
A bibliographic list of 403 articles dealing specifically with conditioned taste aversions from 1950-1975 is provided. In addition, the references are classified according to six major categories in a topical index. The major categories are Parameters of Conditioning, Physiological Manipulations, Pharmacological Interventions, Methodology, Comparative, and General Information. References were obtained from individual journals in psychology, physiology, pharmacology, and animal behavior and were supplemented and extended by Psychological Abstracts. A final source of references was provided by individual researchers who contributed preprints and reprints.
\end{abstract}

If consumption of a particular substance is followed by poison, the rat decreases consumption of that substance on a subsequent exposure. This phenomenon has been defined as a conditioned taste aversion-conditioned, because of the necessity of an association between the substance and poison; aversion, because the rat apparently avoids consumption of the previously poisoned substance; taste, because this avoidance is a reaction to the taste of the previously poisoned substance. Although initially demonstrated in rats poisoned by $X$-irradiation, conditioned taste aversions have subsequently been extended to include a wide range of taste stimuli, species, and toxins. More recently, the biological adaptiveness, associative nature, and the underlying physiological and pharmacological mechanisms of conditioned taste aversions have been studied. These new approaches and interests have provided a wide range of topics in conditioned taste aversions as well as a rapidly growing literature. The most recent application of conditioned taste aversions to addiction and predation is further expanding this range.

The present bibliography is an attempt to bring the literature from 1950 to 1975 into a workable list. Only articles specifically addressing conditioned taste aversions are included. By this restriction, a number of interesting and importantly related topics have been excluded. More specifically, these topics are mimicry, alcoholism, and specific hungers. These topics are included only when they are directly examined in relation to conditioned taste aversions.

In addition to the alphabetical listing, the articles are cross-referenced in a topical index according to six major categories. These categories should provide an

\footnotetext{
The authors would like to thank the many colleagues who generously contributed information for this bibliography. The authors especially thank V. M. LoLordo for his time and helpful suggestions throughout this project. Requests for reprints should be sent to Anthony L. Riley, Department of Psychology, Dalhousie University, Halifax, Nova Scotia, B3H 4J1. An incomplete listing of convention papers, doctoral dissertations, and master's theses are also available upon request.
}

empirical base of the specific parameters in which conditioned taste aversions operate. A listing of related articles and books, as well as literature and theoretical reviews, should provide a background in the more general and theoretical issues surrounding conditioned taste aversions.

In compiling this bibliography, references were obtained from individual journals in the areas of psychology, physiology, pharmacology, and animal behavior. Psychological Abstracts was used to supplement this search as well as to provide references outside the area of these individual journals. References were also obtained from the bibliography of each individual journal. A final source of references was provided by individual researchers in the area of conditioned taste aversions who contributed both preprints and reprints of related articles.

\section{BIBLIOGRAPHY}

1. ADER, R. "Strain" differences in illness-induced taste aversion. Bulletin of the Psychonomic Society, 1973, 1, 253-254.

2. Ader, R. Effects of early experiences on shock- and illnessinduced passive avoidance behaviors. Developmental Psychobiology, 1973, 6, 547-555.

3. Ahlers, R. H., \& Best, P. J. Novelty vs temporal contiguity in learned taste aversions. Psychonomic Science, 1971, 25, 34-36.

4. Ahlers, R. H., \& Best, P. J. Retrograde amnesia for discriminated taste aversions: A memory deficit. Journal of Comparative and Physiological Psychology, 1972, 79, 371-376.

5. Alcock, J. Animal behavior. New York: Sinauer Press, 1975.

6. Alfiksanyan, Z. A., Buresova, O., \& Bures, J. Modification of unit responses to gustatory stimuli by conditioned taste aversion in rats. Physiological Psychology, in press.

7. Arthur, J. B. Taste aversion learning is impaired by interpolated amygdaloid stimulation but not by posttraining amygdaloid stimulation. Behavioral Biology, 1975, 13, 369-376.

8. Balagura, S., \& S Mith, D. F. Role of LiCl and environmental stimuli on generalized learned aversion to $\mathrm{NaCl}$ in the rat. American Journal of Physiology, 1970, 219, 1231-1234.

9. Balagura, S., Brophy, J., \& Devenport, L. D. Modification of learned aversion to $\mathrm{LiCl}$ and $\mathrm{NaCl}$ by multiple experiences with LiCl. Journal of Comparative and Physiological Psychology, 1972, 81, 212-219.

10. Balagura, S., Ralph, T. L., \& Gold, R. Effect of electrical brain stimulation of diencephalic and mesencephalic structures on the generalized $\mathrm{NaCl}$ aversion after $\mathrm{LiCl}$ 
posoning. Phisiologist, 1972, 15, 77.

11. BARKER. L. M. CS duration, amount, and concentration effects in conditioning taste aversions. Learning and Motivation, in press.

12. Barker, L M., \& SMIth, J. C. A comparison of taste aversions induced by radiation and lithium chloride in CS-US and US-CS paradigms. Journal of Comparative and Physiological Psy'chologv, 1974, 87, 644-654.

13. Barker. L. M., Suarez, E. M., \& Gray, D. Backward conditioning of taste aversions in rats using cyclophosphamide as the US. Physiological Psychology, 1974, 2, 117-119.

14. BarnetT. $\dot{S}$ A. The rat $A$ study in behavior. Chicago: Aldine Press, 1963.

15. Barnett. S A., Cowan, P. E., Radford, G. G., \& PraKash, I. Peripheral anosmia and the discrimination of poisoned food by Rattus rattus L. Behavioral Biology. 1975. 13. $183 \cdot 190$

16. Bauer, E. R.\& Reynolds, E. V., III. D-amphetamine and palatability of a saccharin solution. Psychonomic Sctence, 1971, 23, 3-4

17. Bauermeistek, J, J., \& SchaEffer, R. W. Relations between preconditıoned rate of solution ingestion and rate of post-irradiation intake. Physiology and Behavtor. 1969, 4, 1019-1021

18. Baum, M., FoIdart, D. S., \& Lapointe, A. Rapid extinction of a conditioned taste aversion following unreinforced intraperitoneal injection of the fluid CS. Physiology and Behavior, 1974, 12, 871-873.

19. Beckoff, M. Gustayson, C. R., Kelly, D. J., \& Garcia, J. Technical conment: Predation and aversive conditioning in coyotes. Science, 1975, 187, 1096

20. Berg. D. \& Baenninger, R. Predation: Separation of aggressive and hunger motivation by conditioned aversion. Journal of Comparative and Phystological Psychology, 1974, 86, $601-606$.

21. Berger. B. D. Conditioning of food aversions by injections of psychoactive drugs. Journal of Comparative and Physiological Psichologi. 1972 81. 21-26.

22 Berger. B. D. Wise. C. D., \& Stein, L. Area postrema damage and batt shyness. Journal of Comparatte and Phisiological Psychology, 1973, 82, 475-479.

23. Berman. R. F., \& CanNon, D. S. The effect of prior ethanol experience on ethanol-induced saccharin aversions. Phystology and Biphavior, 1974, 12, 1041-1044.

24. BEsT. M. R. Conditioned and latent inhibition in tasteaversion learning: Clantying the role of learned safety Journal of Experimental Psychology" Antmal Behavtor Processes. 1975. 1,97-113

25. B:st, P. J.. \& ORR, J, JR. Effects of hippocampal lesions on passive avoidance and taste aversion conditioning. Physiology and Behavior, 1973, 10, 193-196.

26 Best, P J.. \& ZuCKeRMAN, K. Subcortical mediation of learned taste aversion. Physology and Behavior, 1971, 7. $31^{\top}-320$.

27 Best, P J., B.est, M. R., \& Ahlers, R. H. Transfer of discriminated taste aversion to a leverpressing task. Psychonomic Sclence. 1971, 25, 281-282.

28. Best, P J. Best, M. R.. \& Lindsey, G. P. The role of cue additrity in sahence in taste aversion conditioning. Learning and Motwation. in press.

29. Best, P. J. Best, M. R., \& Mickley, G. A. Conditioned atersion to distinc environmental stımuli resulting from gastrountestinal distress. Joumal of Comparative and Physiological Pspchology. 1973, 85, 250)-257.

30 BIfDERMAN, G B The search for the chemistry of memory: Recent trends and the logic of investigation in the role (1) cholinergh and adrenergic transmitters. In G. A. Kerkut \& J W Phille (Eds), Progress in neurobiologs ivol 2) ONtod Pergamon Press. 1974. Pp 289-307

31 Biedermat G B. Milgram. N. W. Hejghington. G A. A Siockmar. S. $M$ Memory of conditioned food aversion 1. Hows a L hapedi tunction in rats Quarterl Jixmal of I venmented Pricholog,. 1974. 26 010-615.
32. Boland, F J Saccharin aversicms induced by ithium chloride toxicosis in a backuard conditioning paradigm Alumal Leaming and Behawor, 1973, 1. 3.4.

33. Bolles, R. C. The comparative psychology of learning. The selective assoctation principle: Some problems with "general" laws of learning. In G. Bcrmant (Ed.). Perspectwes on animal behavior. Glenvieu Scott. Foresman, 1973. Pp. 280-306.

34. Bolles, R. C. Learming theory. New York: Holt, Rinehart. and Winston, 1975

35. Bolles, R. C., Riley, A. L., \& Laskowski, B. A. A turther demonstration of the learned safety effec: in food-aversion learnıng. Bulletin of the Psichonomic Society, 1973, 1, 190-192.

36. Bond. N.. DiGiusro, E. Amount of solution drunk is a factor in the establishment of taste aversion Animal Learning and Behavor, 1975, 3, 81-84.

37 BOND. N., \& HARLAND. W. Effect of amount of solution drunk on taste-aversion learning. Bulletin of the Psychonomic Socuety, 1975, 5, 219.220

38. Booru, D A. Conditioned satiety in the rat. Journal of Comparatue and Physiologtcal Psychology. 1972, 81, 457-471.

39. Booth, D. A.. \& Simson, P. C. Food preferences by association with variations in amino acid nutrition. Quarterly Journal of Experimental Psychology. 1971, 23, 135-145.

40. Booth, D. A., \& Simson, P. C. Aversion to a cue acquired b) its association with effects of an antibiotic in the rat Journal of Comparative and Physiological Psychology, 1973. 84. $319-323$.

41. Booth, D. A.. \& Simson, P. C. Taste aversion induced by an histidine-free ammo acid load. Physiological Psychology, 1974, 2. 349-351.

42. Booth, D. A.. Lovett, D., \& McSherry, G. M. Postingestive modulation of the sweetness preference gradient in the rat Joumal of Comparatue and Phystological Psychology. 1972, 78, 485-512

43. Brackbili R. M.. \& Brookshire, K. H. Conditioned taste aversions as a function of the number of CS-US pairs. Pstchonomic Sctence, 1971, 22, 25-26.

44. BrackbIll, R M.. Rosenbush, S. N., \& Brookshire K. H. Acquisition and retention of conditioned taste aversions as a function of the taste quality of the CS. Learning and Motwation, 1971, 2, 341-350.

45. Bradley, R. M. \& Mistretta, C. M. Intravascular taste in rats as demonstrated by conditioned aversion to sodium saccharn. Juurnal of Comparative and Physologual Psychology. 1971. 75, 186-189.

46. Braun, J. J., \& McIntosh, H., JR. Learned taste aversions induced by rotational stimulation. Physiological Psychology. 1973. 1. $301-304$.

47. Braun, J J.. \& SNYDER, D. R. I aste aversions and acute methyl mercur porsoning in rats. Bulletin of the Psychonomic Society. 1973. 1, 419-420.

48 Braun, J. J.. Sitick. T B.. \& Lorden, J. F. Involvement of gustatory neocortex in the learning of taste aversions Physiology and Behaver. 1972, 9.637-641.

49. Braveman, N. S poison-based aboidance learning with flavored or colored water in guinea pigs. Learning and Motlution, 1974, 5, 182-194.

50. Braveman, N. S. Relative salience of gustatory and visual cues in the formation of porson-based food aversions by guinea pigs (Cava porcellus). Behavioral Blology. 1975, 14. 189-199.

51. Braveman, N. S. Formation of taste aversions in rats tollowing prior exposure to sickness Learning and Monvation. in press

52. BrookshiRe, K. H Changes in the rat'; preference for saccharin and sodium chluride solutions following injection of dloxan monohydrate Journal of Comparatwe and Phystological Psichologl. 1974, 87, 1001-1068

5.3 Brookshire, K. H. Function of the "onset of illness" in the preference changes of alloxan-diabetic rats. Journal is Complaratue and Phivologatal Psychology, 1974, 87. $1064 \cdot 10^{-72}$

if Broukshire, K. H. Siewart, C. N., \& Bhagavan, H. N. saccharin atersion in dloxan-dabetic rats. Journai of 
Comparative and Physiological Psychology, 1972, 79, 385-393.

55. BroWder, J. A., Upchurch, W. M., \& Kirky, R. H. Preference for drinking deionized water over $\mathrm{D}_{2} \mathrm{O}$ in the rat Physiological Psychology, 1974, 2, 461-463.

56. Brozek, G., Buresova, O., \& Bures, J. Effect of bilateral cortical spreading depression on the hippocampal theta activity induced by oral infusion of aversive gustatory stimulus. Experimental Neurology, 1974, 42, 661-668.

57. Buchw ald, N. A., Garcia, J., Feder, B. H., \& Bach-y-Rita, G. Ionizing radiation as a perceptual and aversive stimulus. In T. J. Haley and R. S. Snider (Eds.), Response of the nervous system to ionizing radiation. New York: Little, Brown, 1964. Pp. 687-699.

58. Bures, J., \& Buresova, O. Behavioral and electrophysiological analysis of the conditioned taste aversion in rats. In Modern trends in neurophysiology (in Russian), in press.

59. Buresova, O., \& Bures, J. Cortical and subcortical components of the conditioned saccharin aversion. Physiology and Behavior, 1973, 11, 435-439.

60. Buresova, O., \& Bures, J. Cortical and subcortical components of conditioned saccharin aversion in rats. Acta Neurologia Experimentalis, 1973, 33, 689-698.

61. Buresova, O., \& Bures, J. The mechanisms of conditioned saccharin aversion. In H. Matthies (Ed.), Neurobiological basis of memory formation. Berlin: Veb Verlag Volk und Gesundheit, 1974. Pp. 298-313.

62. Buresova, O., \& Bures, J. Functional decortication in the CS-US interval decreases efficiency of taste aversion learning. Behavioral Brology, 1974, 12, 357-364.

63. Buresova, O., \& Bures, J. Functional decortication by cortical spreading depression does not prevent forced extinction of conditioned saccharin aversion in rats. Journal of Comparative and Physiological Psychology, 1975, 88, 47-52.

64. Buresova, O., \& Bures, J. The antagonistic influence of anesthesia and functional decortication on conditioned taste aversion. Activitas Nervosa Superior (Prague), in press.

65. Burghardt, G. M., Wilcoxon, H. C., \& Czaplicki, J. A. Conditioning in garter snakes: Aversion to palatable prey induced by delayed illness. Animal Learning and Behavior, $1973,1,317-320$

66. Cappell, H. D., \& LeBlanc, A. E. Conditioned aversion to saccharin by single administrations of mescaline and d-amphetamine. Psychopharmacologia, 1971, 22, 352-356.

67. Cappell, H. D., \& LeBlanc, A. E. Aversive conditioning by d-amphetamine. In J. M. Singh, L. Miller, and H. Lal (Eds.), Drug addiction: Experimental pharmacology. New York: Futura, 1972. Pp. 99-105.

68. Cappele, H. D., \& LeBlanc, A. E. Punishment of saccharin drinking by amphetamine in rats and its reversal by chlordiazepoxide. Journal of Comparative and Physiological Psychology, 1973, 85, 97-104.

69. Cappell, H. D., \& LeBlanc, A. E. Conditioned aversion by psychoactive drugs: Does it have significance for an understanding of drug dependence? Addictive Behaviors, in press.

70. Cappell, H. D., \& LeBlanc, A. E. Conditioned aversion by amphetamine: Rates of acquisition and loss of the attenuating effects of prior exposure. Psychopharmacologia, 1975, 43, 157-162.

71. Cappell, H. D., LeBlanc, A. E., \& Endrenyt, L. Effects of chlordiazepoxide and ethanol on the extinction of a conditioned taste aversion. Physiology and Behavior, 1972, 9. 167.169 .

72. Cappell, H. D., LeBlanc, A. E., \& Endrenyi, L. Aversive conditioning by psychoactive drugs: Effects of morphine, alcohol, and chlordiazepoxide. Psychopharmacologia, 1973, 29, 239-246.

73. Cappell, H. D., LeBlanc, A. E., \& Herling, S. Modification of the punishing effects of psychoactive drugs by previous drug experience. Joumal of Comparative and Physiological Psychology, 1975, 89, 347.356.

74. Capretta, P. J., Moore, M. J., \& Rossiter, T. R. Establishment and modification of food and taste preferences: Effects of experience. Journal of General Psychology, 1973, 89, $27-46$.
75. CAREY, R. J. Acquired aversion to amphetamine solutions. Pharmacology, Biochemistry, and Behavior, 1973, 1, 227-229.

76. CAREY, R. J. Long-term aversion to a saccharin solution induced by repeated amphetamine injections. Pharmacology, Biochemistry, and Behavior, 1973, 1, 265-270.

77. Carey, R. J., \& Goodall, E. B. Amphetamine-induced taste aversion: A comparison of $\mathrm{d}$ - versus 1-amphetamine. Pharmacology, Biochemistry, and Behavior, 1974, 2, 325-330.

78. CAREY, R. J., \& Goodall, E. B. A conditioned taste aversion induced by $\alpha$-methyl-p-tyrosine. Neuropharmacology, 1974, 13 , $595-600$.

79. Carroll, M. E., \& SMith, J. C. Time course of radiationinduced taste aversion conditioning. Physiology and Behavior, $1974,13,809-812$.

80. Carroll, M. E., Dinc, H. I., Levy, C. J., \& Smith, J. C. Demonstration of neophobia and enhanced neophobia in the albino rat. Journal of Comparative and Physiological Psychology, 1975, 89, 457.467.

81. Chitty, D. (Ed.). Control of rats and mice (Vol. 1). Oxford: Clarendon Press, 1954.

82. Chitry, D. (Ed.). Control of rats and mice (Vol. 2). Oxford: Clarendon Press. 1954.

83. Chitty, D. The study of the brown rat and its control by poison. In D. Chitty (Ed.), Control of rats and mice (Vol. 1). Oxford: Clarendon Press, 1954. Pp. 160-305.

84. ClODY, D. R., \& Vogel, J. R. Drug-induced conditioned aversion to mouse-killing in rats. Pharmacology, Biochemistry, and Behavior, 1973, 1, 477-481

85. Clody, D. E., Vogel, J, R., \& TAuB, P. Chlordiazepoxide antagonism of the acquisition and performance of a conditioned food aversion in rats. Pharmacology, Biochemistry. and Behavior, in press.

86. Colavita, F. B. Saccharine preference in rats as a function of age and early experience. Psychonomic Science, 1968, 12, 311-312.

87. Corcoran, M. E. Role of drug novelty and metabolism in the aversive effects of hashish injections in rats. Life Sciences, $1973,12,63.72$.

88. Corcoran, M. E., Bolotow, I., Amit, Z., \& McCaughran, J. A.. JR. Conditioned taste aversions produced by active and inactive cannabinoids. Pharmacology, Biochemistry, and Behavior, 1974, 2, 725-728.

89. Cort, H. B. Adaptive coloration in animals. London: Methuen, 1940.

90. Coussens, W. R., Crowder, W. F., \& Davis, W. M. Morphine induced saccharin aversion in $\alpha$-methyltyrosine pretreated rats. Psyhopharmacologia, 1973, 29, 151-157.

91. Cullen, J. W. Modification of salt-seeking behavior in the adrenalectomized rat via gamma-ray irradiation. Journal of Comparative and Physiological Psychology, 1969, 4, 524-529.

92. Cullen, J. W. Modification of $\mathrm{NaCl}$ appetite in the adrenalectomized rat consequent to extensive $\mathrm{LiCl}$ poisoning. Journal of Comparative and Physiological Psychology, 1970, 72, 79-84.

93. D'Aмато, M. R. Derived motives. Annual Review of Psychology, 1974, 25, 83-106.

94. Davidson, W. S., III. Studies of aversive conditioning for alcoholics: A critical review of theory and research methodology. Psychological Bulletin, 1974, 81, 571-581.

95. DAvis, J. L. Saccharin aversion acquired during unilateral spreading depression. Physiological Psychology, 1975, 3, 253-254.

96. DAvis, J. L., \& BUREs, J. Disruption of saccharin-aversion learning in rats by cortical spreading depression in the CS-US interval. Journal of Comparative and Physiological Psychology, 1972. 80, 398-402.

97. De Castro, J. M., \& Balagura, S. Fornicotomy: Effect on the primary and secondary punishment of mouse killing by $\mathrm{LiCl}$ poisoning. Behavioral Biology, 1975, 13, 483-489.

98. Der-Karabetian, A., \& Gorry, T. Amount of different flavors consumed during the CS-US interval in taste-aversion learning and interference. Physiological Psychology, 1974, 2. 457.460 .

99. DeUTSCH, R. Conditioned hypoglycemia: A mechanism for 
saccharin-induced sensitivity to insulin in the rat. Journal of Comparative and Physiological Psychology, 1974, 86, 350-358.

100. Deven Port, L. D. Aversion to a palatable saline solution in rats: Interactions of physiology and experience. Journal of Comparative and Physiological Psychology, 1973, 83, 98-105.

101. Dinc, H. I., \& Smith, J. C. Role of the olfactory bulbs in the detection of ionizing radiation by the rat. Physiology and Behavior, 1966, 1, 139-144.

102. Divac, I., Gade, A., \& Wikmark, R. E. G. Taste aversion in rats with lesions in the frontal lobes: No evidence for interoceptive agnosia. Physiological Psychology, 1975. 8, 43-48.

103. Domsan, M. CS preexposure in taste-aversion learning: Effects of deprivation and preexposure duration. Leaming and Motivation, 1972. 3. 389.402.

104. Doman, M. Role of ingestion in odor-toxicosis learning in the rat. Journal of Comparative and Physiological Psychology. $1973,84,507-521$

105. Doman, M. Porson-induced neophobia in rats: Role of stimulus generalization of conditioned taste aversions. Animal Learning and Behavior, 1975, 14, 809-813.

106. Domjan, M. The nature of the thirst stimulus: A factor in conditioned taste-aversion behavior. Physiology and Behavior, 1975, 14, 809-81?.

107. Doman, M., \& Bowman, T. G. Learned safety and the CS.US delay gradient in taste-aversion learning. Learning and Motrvation. 1974, 5, 409-423.

108. Doman, M. \& Wilson, IN. E Specificity of cute to consequence in aversion learning in the rat. Psychonomic Science, 1972, 26. 143-145.

109. Doman, M. \& W Wlson, N. E. Contribution of ingestive behaviors to taste-aversion learning in the rat. Journal of Comparattve and Physiological Psychology, 1972, 80, 403-412

110. Dragorn, $W$ B. Conditioning and extinction of taste aversions with variations in intensity of the CS and LS in two strains of rats. Psychonomic Science, 1971, 22, 303-304

111. Dragoin, W. B., McCleary, G. E., \& MCCleary, P. A comparison of two methods of measuring conditioned taste aversions. Pehavior Research Methods and Instrumenta. ilon, $1971,3,309-310$.

112. Dragoin, W. B., Hughes, G., Devine, M., \& Bentley, J Long-term retention of conditioned taste aversions. Effects of gustatory interference. Psychological Reports, 1973, 33, 511514

113 EckardT, M. J. Conditioned taste aversion produced by the oral ingestion of ethanol in the rat. Physiological Psychology $1975,3,317-321$.

114. Eckardt, M. J., Skurdal, A. J., \& Brown, J. S. Condi tioned taste aversion produced by low doses of alcohol Physiological Psychology. 1974, 2, 89-92.

115. Elxins, R. I. Individual differences in bait shyness: Effects of drug dose and measurement technique Psychological Record, 1973, 23, 349-358

116. Elkins. R. l. Attenuation of drug-induced bast shyness to a palatable solution as an increasing function of its availability prior to conditioning. Behavioral Biology, 1973, 9, 221-226.

117. ElKins, R. L. Conditioned flavor aversions to familiar tap water in rats: Ar adjustment with implications for aversion therapy treatment of alcoholism and obesity. Journal of Abnormal Psychology, 1974, 83, 411-417.

118. Elxins, R. L. Bait-shyness acquisition and resistance to extinction as functions of US exposure prior to conditioning. Physiological Psychology, 1974, 2, 341-343.

119 Elkins, R. L. Aversion therapy for alcoholics: Chemical, electrical, or imaginary? International Joumal of the Addictions, 1975, 10, 157-209.

120. Elsmore, T. F., \& Fletcher, G. V. $\Delta$ 'tetrahydrocannabinol: Aversive effects in rats at high doses. Science, 1972. 175, $911-912$.

121. Elton, C. Research on rodent control by the bureau of animal population September 1939 to July 1947. In D. Chitty (Ed.), Control of rats and mice (Vol. 1). Oxford: Clatendon Dress, 1954. Pp. 1.24.
122. EFspamer, R \& C COW 1. T A depression ot ethano consunption in rats as a result of intraperitoneal injections of pyrazole. Psychonomic Scteyce, 1972, 26, 2C-30.

123. ErsconN, F. Effects of a preterred is a nonpreferred C $S$ in the establishment of a taste aversion. Phystological Psychology. 1973, 1, 5-6.

124 Etscorn, F., \& Miller. R. L. Variation in the strength of conditioned taste-aversion in rats as a function of time of inducement. Physiological Psychology, 1975, 3, 270-272.

125 Etscorn, F.. \& Stephens, R. Establishment of conditioned taste aversions with a 24 hour CS-US interval. Physiological Psychology 1973, 1, 251-253.

126. Farley, J. A., Mclaurin, W. A., Scareorough, B. B., \& Rawt InGs, T. D. Pre-irradiation saccharin habituation: A factor in avordance behavior Psychological Reports, 1964, 14, 491 -496 .

127. FEINBERg, A. Effect of treatmen-test interval and proferrin on $\mathrm{X}$ irradiation-induced saccharin aversion JSAS Catalog of Selected Documents in Psychology, 19:3, 3, 119-141.

128 FEnWick, S.. Mikula, P. J., \& KieIn, S. B. The effect of ditferent levels of pre-exposure to sucrose on the acquisition and extinction of a conditioned aversior. Behavioral Btology, $1975,14,231-235$

129. Fernandez, B.. \& Ternes, J. W. Conditioncd aversion to norphine with lithium chloride in morphine-dependent rats. Bulletin of the Psychonomic Society, 1975, 5, 331-332.

130 Fienuingstad, E. J. Chemical transfer of radiation induced avoldance: A replication. Scandınavian Journal of Psychology. 1972, 13, 145-151

131. Fregly, M. J. Specificity of the sodium chlonde appetite of adrenalectomized rats: Substitution of lithium chloride for sodium chloride. American Journal of Physiology, 1958, 195. 645-653.

132. FrumkIN, K. Interaction of $\mathrm{LiCl}$ aversion and sodiumspecific hunger in the adrenalectomized rat. Joumal of Comparative and Physiological Psychology, 1971, 75, 32.40.

133. Frumkin, K. Effects of deprivation schedule on the maintenance of a pre-operative salt aversion by adrenalectomized rats. Physiological Psychology, 1975, 3, 101.106.

134. Frumkin. K. Failure of sodium- and calcium-deficient rats to acquire conditioned taste aversions to the object of their specific hunger Journal of Comparative and Physiological Psychology, 1975, 89, 329-339.

135. Gadusex, F. J., \& Kal,AT, J. W. Effects of scopolamine on retention of taste-aversion learning in rats. Phystological Psychology, 1975, 3, 130-132.

136. GaleF, B. G. JR, \& CLARX, M M. Social factors in the poison avoidance and feeding behavior of wild and domesticated rat pups. Joumal of Comparatrve and Physiologica' Psychology, $1971,75,341-357$.

137 Galef. B. G, Jn, \& Sherry, 1). F. Nother's milk: A medium tor the transmission of cues reflecting the flavor of mother's diet. Journal of Comparative and Physiological Psychology, 1973, 83, 374-378.

138. Garcia, J. The faddy rat and us. New Scuentist and Sctence Journal, 1974, 49, 254-256.

139. Garcia, J., \& ERVIN, F. R. Gustatory-visceral and telereceptor-cutaneous conditioning: Adaptation in internal and external milieus. Communications in Behavioral Biology, $1968,1,389-415$.

140. Garcia, J., \& ERvin, F. R. Appetites, aversions, and addictions: A model for visceral memory. In J. Wortis (Ed.), Recent advances in biological psychiatn (Vol. 10). New York: Plenum Press, 1968. Pp. 284-293.

141. Garcia, J., \& Hankins. W. G. The evolution of bitter and the acquisition of toxiphobia. In D. A. Denton \& J. P. Coghlan (Eds.), Olfaction and taste. New York: Academic Press, 1975. Pp. 39-47.

142. Garcia, J., \& Kimeldorf, D. J. Temporal relationship within the conditioning of a saccharine aversion through radiation exposure. Journal of Comparative and Physiological Psuchologv. 1957, 50. 180-183. 
143. Garcia, J., \& Kimeldorf, D. J. The effect of ophthalmectomy upon responses of the rat to radiation and taste stimul. Journal of Comparative and Physiological Psychology, 1958, 51, 288-291.

144. Garcia, J., \& Kimeldorf, D. J. Some factors which influence radiation-conditioned behavior of rats. Radiation Research, 1960, 12, 719-727.

145. Garcia, J., \& Kimeldorf, D. J. Conditioned avoidance behaviour induced by low-dose neutron exposure. Nature, $1960,185,261-262$.

146. Garcia, J., \& Koelling, R. A. Relation of cue to consequence in avoidance learning. Psychonomic Science, $1966,4,123-124$

147. Garcia, J., \& Koelling, R. A. A comparison of aversions induced by $\mathrm{X}$-rays, toxins, and drugs in the rat. Radiation Research Supplement, 1967, 7, 439-450.

148. Garcia, J., \& Koelling, R. A. The use of ionizing rays as a mammalian olfactory stimulus. In L. M. Beidler (Ed.), Handbook of sensory physiology (Vol. IV) Chemical senses: (Part I) Olfaction. New York: Springer-Vetlag, 1971. Pp. 449-464.

149. Garcia, J., Clatke, J. C., \& Hankins, W. G. Natural responses to scheduled rewards. In P. P. G. Bateson and P. H. Klopfer (Eds.), Perspectives in ethology. New York: Plenum Press, 1973, Pp. 1-41.

150. Garcia, J.. Ervin, F. R., \& Koelling, R. A. Learning with prolonged delay of reinforcement. Psychonomic Science, 1966, 5. $121-122$

151. Garcia, J., Ervin, F, R., \& Koelling, R. A. Baitshyness: A test for toxicity with $\mathrm{N}=2$. Psychonomic Science, 1967, 7, 245-246.

152. Garcia, J., Ervin, F. R., \& Koelling, R. A. Toxicity of serum from irradiated donors. Nature, 1967, 213, 682-683.

153. Garcia, J., Green, K. F., \& McGowan, B. K. X-ray as an olfactory stimulus. In C. Pfaffman (Ed.), Olfaction and taste. New York: Rockefeller University Press, 1969. Pp. 299-309.

154. Garcia, J., Hankins, W. G., \& Rusiniak, K. W. Behavioral regulation of the milieu interne in man and rat. Science, $1974,185,823-831$.

155. Garcia, J., Kimeldorf, D. J., \& Hunt, E. L. Conditioned responses to manipulative procedures resulting from exposure to gamma radiation. Radiation Research, 1956, 5, 79-87.

156. Garcia, J., Kimeldorf, D. J., \& Hunt, E. L. The use of ionizing radiation as a motivating stimulus. Psychological Review. 1961, 68, 383-395.

157. Garcia, J., Kimeldorf, D. J., \& Koelling, R. A Conditioned aversion to saccharin resulting from exposure to gamma radiation. Science, 1955, 122, 157.158.

158. Garcia, J.. Kovner, R., \& Green, K. F. Cue properties vs palatability of flavors in avoidance learning. Psychonomic Science, 1970, 20, 313-314.

159. Garcia, J., McGowan, B. K., \& Green, K. F. Biological constraints on conditioning. In A. H. Black \& W. F Prokasy (Eds.), Classical conditioning II: Current research and theory. New York: Appleton-Century-Crofts, 1972. Pp. 3-27.

160. Garcia. J., McGowan, B. K., \& Green, K. F. Biological constraints on conditioning. In M. E. P. Seligman \& J. L. Hager (Eds.), Biological boundaries of learning. New York: Appleton-Century-Crofts, 1972. Pp. 21-43.

161. Garcia, J., Hankins, W. G., Robinson, J. H., \& Vogt, J. L. Bait-shyness: Tests of CS-US mediation. Physiology and Behavior, 1972, 8, 807-810

162. Garcia, J., McGowan, B. K., Ervin, F. R., \& Koelling, $R$. A. Cues: Their relative effectiveness as a function of the reinforcer. Science, 1968, 160, 794-795.

163. Garcia, J., Buchwald, N. A., Feder, B. H., Koelling, R. A., \& TEDRow, L. F. Ionizing radiation as a perceptual and aversive stimulus. In T. J. Haley \& R. S. Snider (Eds.), Response of the nervous system to ionizing radiation. New York: Little, Brown, 1964. Pp. 673-686.

164. Gay, P. E., LEAF, R. C., \& ARBLE, F. B. Inhibitory effects of pre- and post-test drugs on mouse killing by rats. Pharmacology, Blochemistry, and Behavior, 1975, 3, 33-45.
165. Gibes, J., Young, R. C., \& S Sith, G. P. Cholecystokinin decreases food intake in rats. Journal of Comparative and Physiological Psychology, 1973, 84, 488-495.

166. Gleitman, H. Getting animals to understand the experimenter's instructions. Animal Learning and Behavior, 1974. 2, 1 -5.

167. Gold, R. M., \& Proulx, D. M. Bait-shyness acquisition is impaired by VMH lesions that produce obesity. Journal of Comparative and Physiological Psychology, 1972, 79, 201-209.

168. Green, K. F. Aversions to grape juice induced by apomorphine. Psychonomic Science, 1969, 17, 168-169.

169. Green, K. F. \& Churchill, P. A. An effect of flavors on strength of conditioned aversions. Psychonomic Science, 1970, 21. $19-20$.

170. Green, K. F., \& Garcia, J. Recuperation from illness: Flavor enhancement for rats. Science, 1971, 173, 749-751.

171. Green, K. F., \& PArker, L. A. Gustatory memory: Incubation and interference. Behavioral Biology, 1975, 13, 359-367.

172. Green, K. F., Holmstrom, L. S., \& Wollman, M. A. Relation of cue to consequence in rats: Effect of recuperation from illness. Behavioral Biology, 1974, 10, 491-503.

173. GreEn, L., \& Rachlin, H. The effect of rotation on the learning of taste aversions. Bulletin of the Psychonomic Society, 1973, 1, 137-138.

174. Green, L., Bouzas, A., \& Rachlin, H. Test of an electric-shock analog to illness-induced aversion. Behavioral Biology, 1972, 7, 513-518.

175. Gross, N. B., Fisher, A. H., \& Cohn, V. H., JR. The effect of rachitogenic diet on the hoarding behavior of rats. Journal of Comparative and Physiological Psychology, 1955, 48, 451-455.

176. Grote, F. W., JR., \& Brown, R. T. Conditioned taste aversions: Two-stimulus tests are more sensitive than one-stimulus tests. Behavior Research Methods and Instrumentation, 1971, 3, 311-312.

177. Grote, F. W.. JR., \& Brown, R. T. Rapid learning of passive avoidance by weanling rats: Conditioned taste aversion. Psychonomic Science, 1971, 25, 163-164.

178. Grote, F. W., JR., \& Brown, R. T. Deprivation level affects extinction ' of a conditioned taste aversion. Learning and Motivation, 1973, 4, 314.319.

179. Gustavson, C. R. Taste aversion conditioning of predators. The Chronicle of the Horse, 1975, 38, 12-13.

180. Gustavson, C. R. Breakthrough on the Honn Ranch. Defenders of Wildlife International, in press.

181. Gustayson, C. R., \& Garcia, J. Aversive conditioning: Pulling a gag on the wily coyote. Psychology Today, 1974, 8. $68-72$.

182. Gustavson, C. R., \& Gustavson, J. C. Spiked lamb dulls coyote appetite. Defenders of Wildlife International, 1974, 49. 293-294.

183. Gustavson, C. R., BretT, L. R., Garcia, J., \& Kelly, D. J. A working model and experimental solutions to the control of predatory behavior. In $\mathbf{H}$. Markowitz and V. Stevens (Eds.), Studies of captive wild antmals. Chicago: Nelson Hall, in press.

184. Gustayson, C. R., Garcia, J., Hankins, W. G., \& Rusiniak, K. W. Coyote predation: Control by aversive conditioning. Science, 1974, 184, 581-583.

185. Halpern, B. P., \& TAPper, D. N. Taste stimuli: Quality coding time. Science, 1971, 171, 1256-1258.

186. Hamilton, L. W., \& Capobianco, S. Consumption of sodium chloride and lithium chloride in normal rats and in rats with septal lesions. Physiological Psychology, 1973, 1. 213-218.

187. Hankins, W. G., Garcia, J., \& Rusiniak, K. W. Dissociation of odor and taste in bait shyness. Behavioral Biology, 1973, 8, 407-419.

188. Hankins, W. G., Garcia, J., \& Rusiniak, K. W. Cortical lesions: Flavor illness and noise-shock conditioning. Behaviora Bılogy, 1974, 10, 173-181.

189. Hargrave, G. E., \& Bolles, R. C. Rat's aversion to 
flavors following induced illness. Psychonomic Sclence, 1971, 23. $91-92$.

190. HaRLow, H. F. Effects of radiation on the central nervous system and on behavior-general survey. In T. J. Haley \& R. S. Snider (Eds.), Response of the nervous system to tonizing radiation. New York: Academic Press, 1962. Pp. 627-644.

191. Harriman, A. E., Nance, D. M., \& Milner, J. S. Discrimination between equimolar $\mathrm{NaCl}$ and $\mathrm{LiCl}$ solutions by anosmic, adrenalectomized rats. Physiology and Behavior. 1968. 3, 887-889.

192. Hinde, R. \& Stevenson-Hinde, J. Constraints on learning. London: Academic Press, 1973.

193. Hobas, S. H., Elkins, R. L., \& Peacock, L. J. Taste-aversion conditioning in rats with septal lesions. Behavioral Biology, 1974, 11, 239-245.

194. Hog AN. J. A. How young chicks learn to recognize food. In R. A. Hinde \& J. Stevenson-Hinde (Eds.), Constraints on learntng. London: Academic Press, 1973. Pp. 119-139

195. Hogan, J. A. Development of food recognition in young chicks: I. Maturation and nutrition. Journal of Comparative and Phy'siological Psychology, 1973, 83, 355-366.

196. Hogan, J. A. Development of food recognition in young chicks. II. Learned associations over long delays. Journal of Comparatwe and Phystological Psychology, 1973, 83, 367-373.

197. Holman, E. W. Some conditions for the dissociation of consummatory and instrumental behavior in rats. Learning and Motivation, in press.

198. Holt, J., Antin, J., Gibes, J., Young, R. C., \& Smith, G. P. Cholecystokinin does not produce bait shyness in rats. Physiology and Behavior, 1974, 12, 497-498.

199. Horowitz, G. P., \& Whitney, G. Alcohol-induced conditioned aversion: Genotypic specificity in mice.(Mus musculus). Joumal of Comparattve and Physiological Psychology, 1975, 89, 340-346.

200. Hulse, E. V., \& Dempsey, B. C. Radiation conditroning: A specific aversion to feeding after a single exposure to 5OR International Journal of Radiation Biology, 1964, 8. 97.99.

201. Hunt, E. L., \& Kimeldorf, D. J. The humoral factor in radiation-induced motivation. Radiation Research, 1967, 30, 404-419.

202. Hunt, E. L., Carroll, H. W , \& Kimeldorf, D. J Humoral mediation of radiation-induced motivation in parabiont rats. Science, 1\%65, 150, 1747-1748.

203. Hutchison, S. L., JR. Taste aversion in albino rats using centrifugal spin as an unconditioned stimulus. Psychological Reports, 1973, 33, 467.470.

204. JACQUET. Y F. Conditioned aversion during morphine mantenance in mice and rats. Physiology and Behavtur, 1973 11, $527-541$

205. Johnson, C. Beaton, R., \& Hall, K. Poison-based avoidance learning in nonhuman prumates: Use of visual cues Physiology and Behavior, 1975, 14, 403-407.

206. Johnston, R. E.. \& Zhorik, D. M. Taste aversions to sexual attractanis. Science, 1975, 189, 893-894.

207. Kakolewski. J. W., \& Valenstein, E. S. Glucose and saccharin preference in alloxan-diabetic rats. Joumal of Comparative and Physiological Psychology, 1969, 68, 31-37.

208. Kalat. J. W. Taste salience depends on novelty, not concentration, in taste-aversion learning in the rat. Journal of Comparative and Physiological Psychology, 1974, 86. 47-50.

209. Kalat, J. W. Taste-aversion learning in infant guinea pigs. Developmental Psychobiology, 1975, 8, 383-387.

210. Kalat, J. W., \& Rozin, P. "Salience": A factor which can override temporal contiguity in taste-aversion learning. Journal of Comparative and Physiological Psychology, 1970, 71. $192-197$

211. Kalat, I W \& Rozin, P. Role of interference in tasteaversion learning. Journal of Comparative and Physiological Psychology, 1971, 77, 53-58

212. Kalat, J. W, \& Rozin, P. You can lead a rat to poison but you can't make him think. In M. E. P. Seligman \& J. L. Hager (Eds.). Biological boundaries of leaming.
New York: Appleton-Century-Crotts, 972. Pp. 115-122.

213. Kalat, J. W., \& Rozin, P. "Lejrned safety" as a mechanism in long-delay taste-aversion learning in rats. Journal of Comparative and Physiological Psychology, 1973. 83. 198-207.

214. Kemble, E. D. \& NaGel, J. A. Failure to form a learned taste aversion in rats with amygdaloid lesions Bulletin of the Psychonomic Soclety, 1973, 2. 155-156.

215. Kesner, R. P, Berman, R. F., Burton, B., \& Hankins, W. G. Effects of electrical stimulation of amygdala upon neophobia and taste aversion. Behavioral Biology, 1975, 13 349-358.

216. Kimeldorf, D. J. Radiation-conditioned behavior. In 'T. J. Haley \& R. S. Snider (Eds.), Response of the nervous system to ionzing radiation. New York: Academic Press, 1962. Pp. 683-690.

217. Kimeldorf, D. I., \& Hunt, E. L. Conditioned behavior and the radiation stimulus. In T. J. Haley \& R. S. Snider (Eds.), Response of the nervous system to ionizing radiation. Boston: Little, Brown, 1964. Pp. 652-661.

218. Kimeldorf, D. J., \& Hunt. E. L. Ionizing radiation. Neural function and behavior. New York:Academic Press, 1965.

219. Kimeldorf, D. J.. Garcia, J.. \& Rubadeau, D. 0 Radiation-induced conditioned avoidance behavior in rats, mice, dnd cats. Radiation Research, 1966, 12, 710-718.

220. Klein, S, B., Barter, M. J., Murphy, A. L., \& Richardson, J. H. Aversion to low doses of mercuric chloride in rats. Physiological Psychology, 1974, 2. 397-400.

221. KRAL. P. A. Interpolation of electroconvulsive shock during CS.US interval as an impediment to the conditioning of taste aversion. Psychonomic Sctence, 1970, 19, 36-37.

222. Kral, P. A. Effects of scopolamine injection durung CS-US interval on conditioning. Psychological Repurts, 1971, 28, 690.

223. KRal. P. A. Electroconvulsive shock during the taste illness interval: Evidence for induced disassociation. Physiology and Behavior, 1971, 7, 667-670.

224. Kral. P. A ECS between tasting and illness: Effects of current parameters on a taste aversion. Physiology and Behavor, 1971, 7, 779-782.

225. Kral. P. A. Localized ECS impedes taste aversion learning. Behavioral Btology. 1972, 7.761-765.

226. Kral, P. A..\& BegGarly, H. D. Electroconvulsive shock impedes association formation. Conditioned taste aversion paradigm. Phvsiology and Behavior. 1973, 10, 145-147.

227 KRAL, P A. \& OMER, V V. ST. Beta-adrenergic receptor involvement in the mediation of learned taste aversions. Psychopharmacologıa, 1972, 26. 79-83.

228. Krane, R. V., \& WAGNER, A. R. Taste-aversion learning with a delayed-shock US Implications for the "generality of the laws of learning." Journal of Comparative and Phystological Psychology, 1975, 88. 882.889.

229 Kulkosky, P. J., Riler, A. L., Woods. S. C., \& KRinsky R. Interaction of brain stimulation and conditioned taste aversion: Osmotically induced drinkıng. Physiological Psychology, 1975, 3, 297-299.

230. Lavin, M. J. The establishment of the sensory preconditioning effect using distinct flavors as sensory preconditioning stimuli. Journal of Comparatuve and Physiological Psychology. in press.

231. LEARY, R. W. Food-preference changes of monkies subjected to low-level irradiation. Journal of Comparative and Physiological Psychology, 1955, 48, 343-346.

232. LeBlanc, A. E., \& Cappell, H. Attenuation of punishing effects of morphine and amphetamine by chronic prior treatment Journal of Comparative and Phystological Psychology, 1974. 87. 691-698

233. LeBlanc. A. E., \& Cappell. H Antagonism of morphineinduced aversive conditioning by naloxone. Pharmacology. Biochemistry, and Behavior, 1975, 3, 185.188.

234. LEHR, P P., \& NACHMAN, M. Lateralization of learned taste aversion by cortical spreading depression. Physiology and Behaveor, 1973, 10, 79-83.

235 LE Magnen. J. La facilitdtion differentielle des reflexes 
d'ingestion par liodour alumentaire. Compte Rendus des Seances de la Soctété de Biologie et de ses Filiales [Paris], 1963, 157, 1165-1170.

236. Le Magnen, J. Habits and food intake. In C. F. Code (Ed.). Handbook of physiology (Secction 6) Alimentary canal (Vol. 1) Control of tood and water intake. Washington, D.C: American Physiological Society, 1967. Pp. 11-20.

237. Le Magnen, J. Olfaction and nutrition. In L. M. Beidler (Ed.), Handbook of sensory physiology (Vol. VI) Chemical senses (Part 1) Olfaction. New York: Springer-Verlag, 1971. Pp. 465-482.

238. Lester, D. M.. Nachman, M., \& Le Magnen, J. Aversive conditioning by ethanol in the rat. Quarterly Journal of Studies on Alcohol, 1970, 31, 578-586.

239. LetT. B. T., \& Harley, C. W. Stimulation of lateral hypothalamus during sickness attenuates learned flavor aversions. Physiology and Behavior, 1974, 12, 79.83.

240. LE VAN, H.. \& Moos, W. S. An effect of DMSO on post-irradiation saccharin avoidance in mice. Expertentia. 1967, 23, $276-277$

241. Le Van, H., \& Moos, W. S. Possible effect of radiation produced hydrogen peroxide on post-irradiation aversion in mice. Experientia. 1967, 23, 749-751.

242. Le Van. H. Moos, W. S., \& Hebron, D. L. Direct and indrect effect of $\mathrm{X}$-irradiation on conditioned avoidance behavior. Medicina Experimentalis, 1968, 18, 161-168.

243. Le Van, H., Moos, W. S., \& Mason, H. C. Attenuation of transterability of radiation-induced behavior by dimethyl sultoxide in mice. Journal of Btological Psychology, 1970, 12. 41.44

244. Levy, C. J., Carroll, M. E., Smith, J. C., \& Hofer, K. G. Antihistamines block radiation-ınduced taste aversions. Sctence, 1974, 186. 1044-1045.

243. Levy, C. J., Ervin, F. R., \& Garcia, J. Effect of serum trom irradiated rats on gastrointestinal function. Nature, 1970 , 225. 463.464

246. Lindesey, G. P., \& Best, P. J. Overshadowing of the less salient of two novel fluids in a taste-aversion paradigm. Physiological Psychology, 1973, 1. 13.15.

247. Lorden, J. F.. Kenfield. M.. \& Braun, J. J. Response suppression to odors paired with toxicosis. Learning and Motivation, 1970, 1. 391-400.

248. Lovetr. D., \& Booth, D. A. Four effects of exogenous insulın on food intake. Quarterly Journal of Experimental Psychology, 1970, 22, $406-419$.

249 Lovett, D., Goonchild, P. \& Booth, D. A. Deptession of intake of nutrient by association of its odor with effects of insulin. Psychonomic Science, 1968, 11, 27-28.

250. MACKAY, B. Conditioned food aversion produced by toxicos is in Atlantic cod. Behavioral Blology, 1974, 12, 347-355.

251. Mackintosh. N. J. The psychology of animal learning. London: Academic Press. 1974

252. Maier, S. F.. Zahorik. D. M., \& Albin, R. W. Relative novelty of solid and liquid diet during thiamıne deficiency determines development of thramine-specitic hunger. Journal of Comparatwe and Physiological Psychology, 1971, 74, 254-262.

253. Malone, P. E.. \& Cox. V. C. Development of taste aversions to individual components of a compound gustatory stimulus. Communications in Behavioral Biology. 1971, 6. $341-344$

254. Marguzes. D. L. Beta-adrenergic receptors in the hypothalamus for learned and unlearned taste aversions. Journal of Comparature and Physiological Psychology. 1970. 73, 13-21.

255. Martin, J. C. Saccharin preference and aversion as a function of irradiation and supplier in the albino rat. Psychonomic Srience, 1968, 13, 251-252.

256. Martin, J. C., \& Ellinwood, E. H.. JR. Conditioned aversion to a preferred solution following methamphetamine injections. Psychopharmacologia, 1973, 29, 253-261.

257. Martin, J. C., \& Ellinwood, E. H., JR. Conditioned aversion in spatial paradigms following methamphetamine injections. Psichopharmacologia, 1974, 36, 323-335.

258. MCFARLAND,D J. Stumulus relevance and homeostasis. In
R. Hinde and J. Stevenson-Hinde (Eds.), Constratnts on learming. London: Academic Press, 1973. Pp. 141-155.

259. McGowan, B. K., Hankins, W. G., \& Garcia, J. Limbic lesions and control of the internal and external environment. Behavioral Biology, 1972, 7, 841-852

260. McGowan, B. K.. Garcia, J., Ervin, F. R., \& Schwartz, J Etfects of septal lesions on balt-shyness in the rat. Physiology and Behavior, 1969, 4, 907-909.

261. MCKeEver. S. Compound 1080 and forest regeneration: Characteristics of the poison in relation to bait shyness, poison shyness, toxicity to rodents, and phytotoxicity to conifer seed. State of Calitornia, Resources Agency, Department of Conservation, Division of Frestry, 1974.

262 Mclaurin. W. A. Postirradiation saccharin avoidance in rats as a function of the interval between ingestion and exposure. Journal of Comparative and Physiological Psychology, 1964, 57, 316-317.

263. Mclaurin, W. A \& Scarborough, B. B. Extension of the interstimulus interval in saccharin avoidance conditioning. Radiation Research. 1963, 20, 317-324.

264. Mclaurin, W. A., Farley, J. A. \& Scarborough, B. B. Inhibitory effect of preirradiation saccharin habituation on conditioned avoidance behavior. Radiation Research. 1963, 18 , 473.478 .

265. Mclaurin, W. A., Scarborough, B. B., \& Farley, J. A. Delay of postirradiation test fluids: $A$ factor in saccharin avoidance behavior. Radiation Research, 1964, 22, 45-52.

266. Mclaurin, W. A. Farley, J. A. Scarborough, B, B. \& Rawlings, T. D. Post-irradiation saccharin avoidance with non-coincident stimuli. Psychological Reports, 1964, 14. 507.512 .

267. Middleton, A. D. Rural rat control. In D. Chitty (Ed.). Control of rats and mice (Vol. 2). Oxford: Clarendon Press, 1954. Pp. 414-448.

268. Miller, C. R., Elkins, R. L., \& Peacock, L. J. Disruption of a radiation-induced preference shift by hippocampal lesions. Physology and Behavior, 1971, 6. 283-285.

269. Miller, C. R., Elkins, R. L., Frazer, J., Peacock, L. J., \& Новвs, S. H. Taste aversion and passive avoidance in rats with hippocampal lesions. Physiological Psychology. 1975. 3. $123-126$.

270. Miller, L. L., \& Drew, W. G. Cannabis: Revieu of behavioral effects in animals. Psychological Bulletin, 1974, 81. $401-417$.

271. Millner, J. R. \& Palfai, T. Metrazol impairs conditioned aversion produced by $\mathrm{LiCl}$ : A time dependent effect Pharmacology. Biochemistry, and Behavior, 1975, 3, 201-204.

272 Mineka. S.. Seligman, M. E. P., Hetrick, M., \& Zuelzer, K. Porsonıng and conditioned drinking. Journal of Comparative and Phystologtcal Psychology, 1972, 79, 377.384.

27.3. Mitchell, D., Kirschbaum, E. H., \& Perry, R. L. Ettects of neophobia and habituation on the posson-induced aroudance of exteroceptive stimuli in the rat. Journal of Experimental Psychology: Animal Behavior Processes. 1975. 1. $47-55$.

274. Morris, D. D., \& Smith, J. C. X-ray-conditioned saccharin aversion induced during the immediate postexposure period. Radiation Research, 1964, 21, 513-519.

275. Morrison, G. R., \& Collyer, R. Taste-mediated condithoned aversion to an exteroceptive stimulus following $\mathrm{LiCl}$ poisoning. Journal of Comparative and Physiological Psychology. $1974.86 .51-55$.

276. Mountuoy, P. T. \& Roberts, A. E. Radiation produced avordance to morphine. Psychonomic Science, $1967,9,427-428$

277. Murphy, L. R., \& Brown, T. S. Hippocampal lesions and learned taste aversion. Physiological Psychology, 1974, 2. 60-64.

278. NaChMAN. M. Taste preferences for lithium chloride by adrenalectomized rats. Amercan Journal of Physiology. 196.3. 205. 219-221.

279. NACHMAN, M. Learned aversion to the taste of lithium chloride and generalization to other salts. Journal of Comparatwe and Phystological Psychology, 1963, 56, 343-349 
$280 \mathrm{~N}_{\mathrm{AC}} \mathrm{HM}$ AN. M. Learned taste and temperature asersions due to hithium chloride sickness after temporal delays Journal or Comparatue and Physiologtcal Psychologiv 1970. 73. 22.30.

281. NAC HMAN, M. Limited effects of electroconvulsive shock on memory of taste stimulation. Journal of Compurative and Physiological Psychology. 1970, 73, 31-37

282 NaChMAN. M.. \& AShE. J. H. Learned taste aversions in rats as a function of dosage. concentration, and route of administration of $\mathrm{LiCl}$ Physiology and Behavior. 973,10 $73-78$.

283 NaChman. M. \& Ashe. J. H. Effects of basolateral amigdala lesions on neophobia, learned taste aversions, and sodium appetite in rats. Journal of Comparateve and Phistological Pachology 1974. 87, 622-643

284 Nachman, M.. \& Cole, L. P Role of taste in specific hungers. In L M. Beidler (Ed.), Handbook of senson phisiology (Vol. IV) Chemucal senses (Part 2) Taste. New York Springer-Verlag. 1971. Pp. 337-362.

285. Nachman, M. \& HaRtLey, P. L. The role of illness in producing learried taste aversions in rats: A comparison of several rodentic des. Journal of Comparative and Physiological Psychology, in press

286. Nachman M \& Jonfs D. R. Learned taste aversions over long delays ir rats The role of learned satety. Journal of Comparative and Phisiological Psychology. 1974 86. 949-956.

287 Nachman. M. Lester D. \& Le Magne I Alcohol arersion in the rat: Behavioral assessment of noxious drug eftects Sctence. 1970. 168. 12441246.

288. NaKaJima. $S$ Conditioned aversion of water produced by cictoheximide injection. Phisiological Psychologv. :974. 2. 484.486

289. NATHAN. B. A. \& Vogel, J. R. Taste aversions induced by d-amphetamine. Dose-response relationship. Bulletin of the Psychonomic Soctetv, 1975. 6. 287.288.

290. Nowlis, $G \mathrm{H}$. Conditioned stimulus intensity and acquired alimentary aversions in the rat. Journal of Comparatre and Phisiological Psichologi. 1974. 86. 1173-1184.

291 O'Boyle. M.. LoONey. T. A.. \& Cohen, P $S$. Suppression and recovery of mouse killing in rats following immediate lithium-chloride injections. Bulletin of the Psychonomic Society, 1973, 1. 250-252.

292. OMER, V V ST., \& Kral, P. A Electroconvulsive shock impedes the learning of taste aversions: Absence of blood-brain-bartor involvement Psychonomic Science. 1971. 24. $251-252$

293. Omutra. K. Takagi, S. F.\& Harada. O. On the mechanism of the repellant action of naramycin to rats. Gunma Journal of Medical Sclences. 1901.10.217.227.

294. Pais, I. F. \& Booth, D. A. Toxiphobia for odors. Phichonomic Silence, 1968, 10. 363-364.

295. Parker. L. F. \& Radow. B. L. Morphine like physical dependence A pharmacological method for drug assessment using the rat Pharmacology. Bochemistry, and Behavior. 1974. 2.613-618

296. Parker, L F. Failor, A , \& Weidman, K. Conditioned preferences in the rat with an unnatural need state: Morphine withdraual. Joumal of Comparative and Phystological Psychology. 1973. 82, 294-300.

297. Pracock. L. J, \& Watson. J. A. Radiation-induced aversion to alcohol. Science, $1964,143,1462-1463$

298. Peck. J. H., \& Ader, R Illness-induced taste aversion under states of deprivition and satiation. Animal Learning and Behavior. 1974, 2, 6-8

299. Pfrry. N W.. JR. Avoidance conditioning of $\mathrm{NaCl}$ with X-irradiation of the rat. Radiation Research $1 * 3,20$ 471.476

300). Peters, R. H., \& Reich, M. J. Effects of ventromedial hypothalamir lesions on conditioned sucrose aversions in rats. Gournat of Comparative and Phystological Psychologv. 1673. 84. 502.506

36. Prakash, I. Jain, A P. Ball shyness of thi gerbils "atera indka Harduicke and Menones humonat Jerdon Annals of Appled Bologi, 1971, 69.169-172
302 Prakash, 1, Rana B \& Jin. A P. Balt shyness in thi.: spectes of Rattus Zettschrit fur Angewandte Zoologie, m prises

303 RALPH. T L \& BALAGCRA, S Effect of intracranial electrical stimulation on the primary learned aversion to $\mathrm{LICl}$ and the generalyed aversion to $\mathrm{NaCl}$ Journal of Comparatry und Phisiological Pswchologi, 197.4.86 664-669.

304 REVLSKY. S H. Aversion to sucrose produced by contingent X-irtidiation. Fimporal and dosage parameters. Journal of Comparatue and Phystological Psychology, 1968, 65, 17-22.

305 Revusky. S $\mathrm{H}$. The role of interference in association over I delay. In W K Honig and $\mathrm{H}$. Jame's (Eds.i. Animal memon: Neu York Academic Press. 1971 Pp. 155213.

300. Revusky. S H Some laborator; paradigms for chemical aversion treatment of alcoholism Joumai of Behavior Therapy and Expenmental Psychatn: 1973. 4. 15-17.

307. Revusky.S. H \& Bedarf. E. W Association of illness with ingestion of novel foods. Science, 1967, 155, 219-220.

308. Revusky S H. \& De Vencto, F Attempt to transfer aversion is saccharin solution by injection of RNA from trained to nawe rats. Journal of Biclogical Psvcholog 1967. 9. 18-22.

309 Revisky. S., \& Garcia. J. Learned as rociations over long delars In G H Biner and I T Spence (Eds), Psychology of learning and mothation Advunces $n$ research and theon (Vol IV). Neu York Academic Pres; 1970 Pp 1-84.

310. Revisky S H. Gorry. I Flabor aversions produced bs contingent drug injection Relatre ettects ent'ss of apomorphine emetine. and lithium Behalor Rese arich and Theraps, 1973 11. $403-409$

311 Revisky, S H. \& lalkulis H. K. Effects of alcoho and hithum habituation on the development of alcohol aversions through contingent lithim injection. Behavior Reseurch and Theraps. 1975, 13,14

312 Revusky, S H., Taukulis, H. K., \& Peddee, C. Learned association between pentobarbital sedation and later lithium sickness in rats. Pharmacology, Biochemistry, and Behanor, in press.

313. Richter, C P. Taste and solublity of toxic compounds in porsoning rats and man. Journal of Comparative and Physiological Psychology, 1950, 43. 358-374.

314 Richter, C P. Experimentally produced behavior reactions to food potsoning in wild and domesticated rats Annals of ihe New York Academy of Sciences, 1953, 56. 225-239.

315. RiEge. W H. Possible olfactory transduction of radiation induced aversion. Psychonomic Sclence. 1968, 12, 303-304.

316. RIEGE, W. H. Distuption of radiation-induced aversion to saccharin br electroconvulswe: shock Phystology and Behavior. $1969,4,15^{7} \cdot 161$

317 RoLL, D. L \& SMITH, I C. Conditioned taste aversion in anesthetized rats In M. E P Seligman and J. L. Hager (Eds). Butogical boundaries of learning Nex York. AppletonCentury Crofts. 1972. Pp 98102

318. Roll. D , Schaeffer, R W., \& Smith. I ( Effects of a condutioned taste aversion on schedule-induced polydipsıa Psychonomic Science, 1969 16. 39-41.

319. Rolis, B. J. \& Roics. E. T. Effects of lesions in the basolateral amygdald or: flud untake in the rat. Joumal of Comparatue and Physlological Psychology, 1473. 83. 240-247.

320 Rory S R. Sc hwartz. M \& \& Teitelbaum P. Failure of recovered lateral hypothalamic rat" to learn spectic food aversions Journal of Comparatne and Physiological Psychology. $1973,83,184-197$

321 Rozin. P. Thramane specific hunger. In C. F Code (Ed.) Handbook of physiology (Section 6) Alimentury canal (Vol 1) Contml of tood and water intake Washington. D.C: American Physiological Society. 1967. Pp. 411-431

322 Ruzin. P Spectic aversions as a component of specific hungers Joumal of Compuratre ana Physological Psychology. $197^{-}$. 64. $237-242$

323 Rozin P Specofic aversions and neophobla resulting from utumy deficienc, or porsoning in half-wild and domestic rats loumol of Comparative and Phvstological Psichologi'. 145.466 .8288 
324. RoziN. P. Central or peripheral mediation of learning with long CS-US intervals in the feeding system. Journal of Comparative and Physiologucal Psychology, 1969, 67, 421-429.

325. Rozin, P. Adaptive food sampling patterns in vitamin deficient rats. Journal of Comparattve and Physiological Psychology. 1969. 69. 126-132.

326. Rozin. $P$ The selection of foods by rats. humans. and other animals. In J. Rosenblatt. R. A. Hinde. C. Beer, \& E. Shaw (Eds.), Advances in the study of behavor (Vol, VI), Neu York: Academic Press. 1975.

327. Rozin, P., \& KalaT, J. W. Specific hungers and poison avordance as adaptive specializations of learning. Psychological Review, 1971. 78, 459-486.

328. Rozin, P., \& Kalat, J. W. Learning as a situationspecific adaptation. In M. E. P. Seligman and J. L. Hager (Eds.). Bological boundaries of learning. New York: Appleton-Century-Crofts. 1972. Pp. 66-96.

329. Rozin, P.. \& REE, P. Long extension of effective CS-US interval by anesthesia between CS and US. Journal of Comparative and Physiological Psychology, 1972, 80, 43-48.

330. Rozin, P.. \& Rodgers, W. Novel-diet preferences in vitamin-deficient rats and rats recovered from vitamin deficiency, Journal of Comparative and Phvsiological Psychology. 1967. 63. $421-428$.

331 Rusak. B., \& ZuCKER. I. Fluid intake of rats in constant light and during feeding restricted to the light or dark portion of the illumination cycle. Physiology and Behavior, 1974, 13 $91 \cdot 100$.

332. Rzoska, J, Bait shyness, a study in rat behaviour. The Britush Journal of Animal Behaviour, 1953, 1, 128-135.

333. Rzoska, J. The behaviour of white rats towards poison baits. In D. Chitty (Ed.), Control of rats and mice (Vol. 2). Oxford. Clarendon Press, 1954. Pp. 374-394.

334. Scarborough, B. B., \& Mclaurin, W. A. The effect of intraperitoneal injection on aversive behavior conditioning with X-itradiation. Radiation Research, 1961, 15, 829-835.

335. Scarborough, B. B.. \& Mclaurin, W. A. Saccharin avoidance conditiontng instigated tmmediately after the exposure period. Radtation Research, 1964, 21. 299-307.

336. Scarborough, B. B.. Whaley, D. L., \& Rogers, J. G. Saccharin avoldance behavior instigated by $\mathrm{X}$-irradiation in backuard conditioning paradigms. Psychologıcal Reports. 1964. 14. 475-481

337. Schaefrer. A. A. Habit formation in frogs. Journal of Antmal Behavtor. 1911. 1. 309-335.

338. Schaeffer, R. W.. \& Smith, J. C. Lick rates in rats exposed to gamma-irradiation. Psychonomic Science, 1966, 6, 201-202.

339. Schaeffer. R, W.. Hunt, E L., \& Kimeldorf. D. J Application of Premack's theory to a classically conditioned sucrose aversion induced by $\mathrm{X}$-ray exposure. Psychological Record, 1967. 17, 359-367.

340 Schwartz. B. On going back to nature A revien of Seligman and Hager's biological boundaries of learning. Journal of the Experimental Analysts of Behavior. 1974, 21 , $183-198$

341. Schwartz. M.. \& Teitelbaum. P. Dissoclation between learning and remembening in rats with lesions in the lateral hypothalamus. Joumal of Comparative and Physiological Psichology. 1974, 87, 384-398.

342 Seligman. M. E. P. On the generality of the laws of learning. Psychological Review. 1970. 77. 400-418.

343. Seligman. M. E. P. Phobias and preparedness. Behavior Therapy. 1971, 2. 307-320.

344. Seligman. M. E. P., \& Hager. J. L Biological boundanes of leaming. New York: Appleton-Century-Crofts. 1972.

345. Seligman, M E. P.. \& Hager. J. L. Biological boundanes of learning: The sauce-beamaise syndrome. Psychology Today, 1972, 6. 59-61.

340. Sew ard. 1. P., \& Greathouse. S. R. Appetitive and arersive conditioning in thramine-deticient rats. Journal of Compurative and Physological Psychology, 1973, 83. 157-167.
347. Shettlen orth, S. J. Constraints on learning. In D. S. Lehrman. R. S. Hinde, and E. Shaw (Eds), Advances in the study of behavior (Vol. IV). New York: Academic Press, 1972. Pp. 1-68.

348. SHORTEN, M. The reaction of the brown rat towards changes in its environment. In D. Chitty (Ed.). Control of rats and mice (Vol. 2). Oxford: Clarendon Press, 1954. Pp. 307-334.

349 SiEgel, S. Flavor preexposure and "learned safety." Journal of Comparative and Physiological Psychology, 1974, 87. 1073-1082.

350. SimSON, P. C. Effects of CS-US interval on the conditioning of odour preferences by amino acid loads. Physiology and Behavior. 1973, 11, 801-808.

351. Simson, P. C., \& Booth, D. A. Olfactory conditioning by association with histidine-free or balanced amino acid luads in rats. Quarterly Joumal of Experimental Psychology, 1973. 25. 354-359.

352. Simson, P. C., \& Booth, D. A. The rejection of a diet which has been associated with a singie administration of an histidine-free amino acid mixture. British Journal of Nutrition, 1974, 31. 285-296.

353 Sмrтн. C. U. M. Discrimination between heary water and water by the mouse. Nature, 1968, 217, 760 .

354. Smith, D. F., \& Balagura, S. Role of oropharyngeal factors in $\mathrm{LiCl}$ aversion. Journal of Comparattve and Physiological Psychology, 1969, 69. 308-310.

355. Smith, D. F., Balagura, S., \& Lubran, M. Some effects of adrenalectomy on $\mathrm{LiCl}$ intake and excretion in the rat. American Joumal of Physiology, 1970, 218, 751-754.

356. SмIтн, J. C. Radiation as an aversive stimulus. American Zoologist, 1967, 7, 402 .

357. Sмттн. J. C. Radiation: Its detection and its effects on taste preferences. Progress in Physiological Psychology, 1971. 4. 53-118.

358. Smith, I. C., \& Birkie, R. A. Conditioned aversion to sucrose in rats using $X$-rays as the unconditioned stimulus. Psychonomic Science, 1966, 5, 271-272.

359. Smith, J. C., \& MorRis, D. D. Effects of atropine sulfate on the conditioned aversion to saccharin fluid with X-rays as the unconditioned stimulus. Radiation Researcn, 193, 18. $186-190$

360. Smith, J. C., \& Morris, D. D. The use of $\mathrm{X}$ rays as the unconditioned sumulus in five-hundred-day-old rats. Journal of Comprarative and Physiological Psychology, 1963, 56, 746-747.

361. Smith, J. C., \& Morris, D. D. The effects of atropine sultate and physostigmine on the conditioned aversion to saccharn solution with $\mathrm{X}$-rays as the unconditioned stimulus. In T J. Haley and R. S. Snider (Eds.). Response of the nervous system to tonizing radiatton. New York. Little. Brow n. 1964. Pp. 662-672.

362. Smirk. J. C.. \& Roll, D. L. Trace conditioning with $\mathrm{X}$-rays ds an aversıve stımulus. Psychonomic Science. 1967, 9. $11-12$.

363. Smith, J C., \& SchaffFer, R. W. Development of water and saccharin preferences after simultaneous exposures to saccharin solution and gamma rays. Journal of Comparattve and Phystological Psychology. 1967, 63, 434-438.

364. Smith, J. C., Morris, D. D., \& Hendricks, J. Conditioned aversion to saccharin solution with high dose rates of $\mathrm{X}$-rays as the unconditioned stimulus. Radiation Research. 1964, 22. 507-510.

365. SMith, J. C., TA Ylor, H. L.. MORRis, D. D., \& Hendricks, $\mathrm{J}$. Further studies of $\mathrm{X}$-ray conditioned saccharin aversion during the postexposure penod. Radiation Research, 1965, 24, 423-431.

366. SMITH, R. G. The role of alimentary chemoreceptors in the development of taste aversions. Communications in Behavtoral Btology, 1970, 5, 199-204.

367. Smitr, R. G. Intake differentiation by rats of equimolar sodium chlonde and lithium chloride solutions. Psychonomic Sclence, 1971, 23, 11-12.

368. Southern, H. N. Control of nats and mice (Vol. 3). Oxford Clarendon Press, 1954

369 Strom. C., Lingenfelter, A., \& Brody, J. F. Discrimination of lithium and sodium chloride solutions by rats. 
Ps.rchonomic Science. 1970. 18. 290-291

370. Supak, T. D.. Macrides, F.. \& Chorover, S. L The bait-shyness effect extended to olfactory discrimination Communcatons in Behavioral Biology, 1971, 5. 321-324.

$3^{-1}$ Sutker. L. W. The effect of initial taste preference on subsequent radiation-induced aversive conditioning to a saccharin solution. Psychonomic Science, 1971, 25, 1-2.

372 Tapper. D. N., \& Halpern, B. P. Taste stimul1: A behavoral categorization. Science, 1968, 161, 708-710

373. Taukulis, H. K. Odor aversions produced over long CS-US delays. Behavioral Biology, 1974, 10. 505-510.

374. Taukulis, H. K., \& Revusky, S. H. Odor as a conditioned in hibitor: Applicability of the Rescorla-Wagner model to feeding behav tor. Learning and Motivation, 1975, 6, 11-27.

375. Ternes. J. W. Circadian cyclic sensitivity to gamma radiation as an unconditioned stimulus in taste aversion conditioning. In L. E. Scheving, F. Halberg, \& J. E. Pauly (Eds.), Chronobiology Tokyo: Igaku Shoin, 1974. Pp. 544-547

376. Ternes. J. W. Conditioned aversion to morphine with naloxone. Bulletin of the Psychonomic Society, 1975, 5, 292-294.

377. Ternes. J. W. Naloxone-induced aversion to sucrose in morphine-dependent rats Bulletin of the Psychonomic Society. 1975. 5. 311-312.

378. Tномка, M L., \& Brown, T. S. The effect of hippocampai lestons on the development and extinction of a learned taste aversion for a novel food. Physiological Psychology, 1975, 3. $281-284$.

379. Thompson, $H . \quad V$ The consumption of plain and porsoned cereal batts by the brown rat. In D. Chitty (F.d) Control of rats and mice (Vol. 2). Oxford: Clarendon Press. 1954. Pp. 352-373.

380 VOGEL, J $R$ Antagonism of a learned taste aversion tollowing repeated aministrations of electroconvulsive shock Physiologicul Psichology, 1974, 2. 493-496.

381. VoGFL, J. R. Conditioning of taste aversion by drugs of abuse. In H. Lal and J. Singh (Eds.), Neurobiology of drug dependence (Vol. I) Behavioral anabysis of drug dependence. New York: Futura, 1975

382. VOGEL. J. R., \& CLODY. D. E. Habituation and conditioned food aversion. Psychonomic Sctence, 1972. 28, 275-276

383. Vogel. J. R., \& Nathan, B. A. Learned taste aversions induced by hypnotic drugs. Pharmacology. Biochemistry, and Behavor. 1975. 3. 189-194.

384. Vogel. J, R, \& Nathan, B. A. Learned taste aversions induced by high doses of monosodium l-glutamate. Pharmacology, Blochemistr, and Behavior, in press.

385. Watson. J. S. Control of the ship rat (Ratus rattus) in London. In D. Chitty (Ed). Control of rats and mice (Vol. 2). Oxfurd. Clarer,don Press, 1954. Pp. 490-499.

386. WatSON, J \$ \& PERRY, J. 5 Experiments on ral contral in Palestine and the Sudan. in D Chitty (Ed). Control of rass and mece (Vol 2). Oxtord Clarendon Press. 1954 Pp. $500-521$

$38^{7}$ Weisinger, R. S., Parker, L. F.. \& Skoruptski, J. D Conditioned taste aversions and specific need states in the rat.
Journal of Comparsabe and Phisiologinal Piychology 1974, 87 655.660 .

388. Weisman, R. N., \& Hamil.ton. L, W Increased conditioned gustatory aversion following VMH lesions in rats. Physiology and Behatior, 1972, 9. 801-804.

389. Whaley, D. L. Scarborough, B. B. \& Reichard, S. M. Traumatic shock. X-irraơration, and avoldance behavior. Physiology and Behavror, 1966, 1, 93-95.

390. WICKLER. W. Mimicry in plants and anımals. Neu York McGraw-Hill. 1968.

391 Wilcoxon, H. C. Dragoin, W. B , \& Kral, P. A. Illness. induced aversions in rats and qual: Relative salience of visual and gustatory cues. Sclence, 1971. 171. 826-828.

392. WING, I, F. \& BIRCH, L. A. Relative cue properties of novel-tastıng substances in avoidance conditioning. Antmal Le'aming and Behavior. 1974. 2. 63-65.

393. Wise, R. A.. \& Albin. J. Stimulation-induced eating dirrupted by a conditioned taste aversion. Behavoral Biology. 1973, 9. 289-297

394 Wittlin, W. A.. \& Brookshire. K. H. Apomorphineinduced conditioned aversion to a novel food. Psychonomic Silence, 1968, 12,217-218

395 Woods, S. C.. Weisinger, R. S.. \& Wald. B. A. Conditioned aversions produced by subcutaneous injections of Formalin in rats. Journo? of Comparative and Phystological Psichology, 1971, 77, 410-415

396 Woods, S. C.. Lawsom. R.. Haddad, R, K.. Rabe, A.. \& Lawson. W. E. Reversal of conditioned aversions in normal and micrencephahe rats. Joumal of Comparative and Phystological Psychology, 1974, 86. 531-534.

397 Wright, W. E., Foshee, D P.\& MCCleary. G. E Comparison of taste aversion with various delays and ciclophosphamide dose levels. Psychonomic Science. 1971. 22. 55.56 .

398. Zahler, C. L., \& Harper, A. E. Effects of dietary amino acid partern on food preference behavior of rats Journal of Comparative and Physiological Psuchology, 1972, 81. 155.162.

399 ZA HORIK, D. M. Conditioned physiological changes associated with learned aversions to tastes paired with thiamine defictency in the rat. Journal of Comparative and Physiological Psychology, 1972. 79, 189-209.

400. ZahoruK, D. M., \& BEAN, C A. Resistance of "recovery" tlavors to later association with illness. Bulletin of the Psychonomic Society, 1975. 6, 309-312.

401 Zahorik, D. M, \& Johnston, R. E. Taste aversions to food flavors and vaginal sectetion in golden hamsters. Journal of Com jarative and Phystologtcal Psychology, in press. 402 ZAHORIX, D M. \& MAIER, S F. Appetitive conditioning uith recovery from thiantne defictency as the unconditioned stimulus Psychonomis Sctence. 1969, 17. 309.310.

403 Zahorik, D M., Maler. S. F.\& Pies. R. W Preferences for tastes pared with recctery irom thamine deficiency in rats: Appetituve conditioning or leirned safely. Journal of Comparative and Physological Psychology. 1974, 87, 1083-1091.

\section{TOPICAL INDEX}

\section{PARAMETERS OF CONDITIONING Conditioned Stimulus Modality}

TASTE

Acetic acid, 399

Almond. 396

Amphetamine, 75

Anise, $3,4,25,252,402$

Appie. 187,190

Banana. 252. 402

Bartum, 200

Cabbage, 401

Carrot. 401

Casein hydrolysate $28,210,211,212,213$ 324.329
Cat food, 393

Cherry, 190

Chicken. 248

Chocolate, 22, 189, 219, 320

Cinnamon, 252

Citric acid. 44

Cocoa, 252

Coconut. $320,341,345$

Coffee, $98,99,212,230,239,349$

Deer, 181

Deionized water. 55. 353

Earthworms, 65, 337

Ethanol. 23, 113, 287, 297, 311, 334

Glucose. 248. 253. 294. 366

Grape. 114, 168, 169, 170,190, 215, 307. 394

Ground nut oll zinc phosphate, 301
Hambuiger. 181, 184

Hairy caterpillar, 33 ?

Honer. 378

Hydrochloric acid. 1, 2, 49, 110, 112, 123. $125,153,221,224,374,391$

Isopropanol. 247

Lamb. 181,184

Lemon. 203. 248

Lithium chloride, $8,10,92,132,146,147$ $17-186,234,239,279,303,319,354$ $355,367,369,370$

Maple. 320, 341, 395, 396

Mealuorms, 337

Mice. 20,84, 97, 164, 291

Milk, 21, 85, 169, 170, 289, 307, 380, 382, 38 38. 384. 388, 394

Millet seted. Is 
Morphine sulfate, $129,276,376$

Mother's milk, 137

Orange, 114, 341

Quinine, 47, 153, 399

Quinine/saccharin, 254

Rabbit. 181, 184

Rat Chow, 155

Root beer, 341

Saccharin, 3, 4, 6, 7, 11, 12, 13, 16, 17 $20,23,24,25,26,27,28,29,30,31,32$, $35,36,37,41,43,44,45,47,48,49,50$, $51,52,53,54,56,58,59,60,62,63,64$, $66,67,68,70,71,72,73,76,77,78,79$, $80,87,88,90,95,96,101,102,103$, 104, 105, 106, 107, 108, 109, 111, 115, $116,118,120,123,124,126,127,130$, $134,142,143,144,145,146,147,150$, $151,152,153,157,158,165,167,172$. $173.174,176,178,187,188,190,193$, $197,198,199,201,202,204,208,214$. $219,222,223,225,226,227,228,229$. $230,232,233,238,239,240,244,246$, $255,256,257,259,260,262,263,264$, $265,266,268,269,271,272,274,275$, 280, 281, 286, 287, 292, 294, 295, 298, $310,312,315,316,317,318,324,331$, $334,335,336,338,339,346,359,360$. $361,362,363,364,365,366,371,372$, $374,375,389,392,397,399,400$

Saccharın/cyclamate, 18

Saccharin/glucose, 253

Sodium chloride, 9, 28, 29, 41, 44, 45, 46, $52,53,54,87,91,98,100,107,133$ $134,185,186,210,211,212,213,290$ $299,366,374$

Strawberry, 22, 189

Sucrose, 46, 98, 128, 135, 209, 210, 211 $212,213,220,275,277,282,283,285$. $300,304,307,329,358,362,377,387$

Sucrose/casein hydrolysate, 136

Sucrose-octa-acetate, 296

Thiamine deficient diet, 322, 323

Vaginal secretion, 206, 401

Vanilla, 24, 28, 87, 210, 212, 246, 252, $320,400,402$

Vinegar, 98, 147, 208, 230, 349, 366

Water, $16,46,47,51,73,104,117,125$ $126,145,147,150,155,157,201,202$, $204,212,228,247,256,262,263,265$, $206,275,280,288,311,334,335,336$, $358,359,361,363,365,372,389$

Olfaction

Acetone, 247

Amylacetate, 370, 373, 374

Benzyl acetate, 40

Chocolate, 189

Citral, 235, 294

Eucalyptus, $39,235,248,350,351,352$

Geraniol. 40, 247

Isopropanol, 247

Lemongrass, 39, 248, 294, 350, 351, 352

Mentholatum. 104

Peppermint, 187

Perfume, 147

Sodium chloride, 9

External. Cues

Black box, 29, 257

Blue box. 205

Blue water, 49, 391

Bright/nolsy water, 146,172

Food containers. 273. 324
Gray box, 189, 257

Houselight, 275

Location, 367

Large and small pellets, 162

Red water, 49, 50

Striped box, 189

Temperature. 153, 280

Visual/auditory/tactile cues, 147

Wet and dry food, 161

White noise, 108

Yellow tube, 205

\section{Parametric Comparisons}

Amount, 11, 36, 37, 98, 103

Concentration, $11,17,18,45,50,53,75$,

$100,110,130,188,208,247,276,290$,

$324,339,358$

Duration, 11, 98, 103

\section{Unconditioned Stimulus} Range

Chemical

Alcohol. 334

Alloxan monohydrate, $52,53,54$

Alpha-methylparatyrosine, 78, 90

Amobarbital, 383

Apomorphine, 3, 4, 24, 25, 26, 27, 28, 43, $44,147,150,167,168,169,170,172$. $198,215,246,310,324,394$

Atropine sulfate, 359,361

Calcium chloride, 337

Cannabichromene, 88

Cannabigerol, 88

Cannabidiol, 88

Chloral hydrate, 383

Chlordiazepoxide, 68, 72, 73

Chloroprothixene, 317

Chlorpheniramine maleate, 244

Chlorpromazine, 21, 68

Cholecystokinin, 165, 198

Copper sulfate, 285

Cycloheximide, 40,288

Cyclophosphamide, 1, 2, 35, 48, 110, 111 ,

$112,115,116,117,118,123,124,125$,

$151,161,176,178,221,247,269,290$.

$294,298,391,397$

d-amphetamine, $16,21,22,51,66,67,68$,

$70,73,75,76,77,164,232,235,289$

deionized water, 55,353

Delta-1-THC, 87

Delta-8-THC, 88

Delta-9-THC, 88, 120

Dimethyl sulfoxide, 240

Emetıne hydrochloride, 310

ethanol, 23, 72, 113, 114, 199, 238

'ether, 21, 201, 383

equithesin, 329

Flurazepam. 383

Formalin. 387. 395

Glucose, 99

Halothane, 329

Hexobarbital, 383

Histam1ne diphosphate, 244

Hypertonic procaine, 272

Hypertonic saline, 189

Imipramine, 21

Insulın, 248, 249, 387

Isotonic procaine, 272

l-amphetamine, 77, 164

1-isoproterenol hydrochloride, 254

Lithium chloride, $6,7,8,9,10,12,18,20$, $30,31,32,36,37,49,50,51,56,58,59$, $60,62,63,64,65,71,92,96,97,98$,
$102,103,104,105,106,107,108,109$ $128,129,132,133,134,135,136,137$, $146,147,158,165,174,177,181,184$ $185,186,187,188,190,197,204,206$, $208,209,210,211,212,213,214,222$ $223,224,225,226,227,229,230,234$ $239,253,259,260,271,272,273,275$ $277,279,280,281,282,283,285,286$, $287,291,292,300,303,310,311,312$ $315,319,320,323,329,331,341,349$ $354,355,366,367,369,370,373,374$, $378,392,393,396,400,401$

Lorazepam, 21

Mercuric chloride, 220

Mescaline hydrochloride, 66

Methamphetamine hydrochloride, 256, 257

Methaqualone, 383

Methylatropine, 84, 380, 382, 388

Methyl mercuric chloride, 47

Methyl scopolamine, 21, 22, 51

Metrazol, 4, 271

Monosodium l-glutamate, 384

Morphine sulfate, $21,72,73,90,204,232$, 233, 296

Myotal, 315

Naloxone hydrochloride, 204, 233, 376, 377

N-butyraldoxime, 287

Nembutal, 271,317

Octapeptide (cholecystokinin), 165, 198

Oxythiamine hydrochloride, 323, 346

P-chlorophenylalamine, 287

Pentobarbital, 312

Phenobarbital, 383

Physostigmine, 361

Plocarpine, 164

Potassium chloride, 59, 60, 62, 63, 96, 234

Proferrin, 127

Pyrazole, 287

Red squill, 285

Scopolamine, 21, 222

Serum from irradiated rats, 130, 152

Serum via vascular anastomosis, 201, 202

SKF 525A, 87

Sodium chloride, 100

Sodium cyanide, 285

Sodium monofluoroacetate, 285

Sodium phenobarbital, 21

Strychnine sulfate, 21, 285

Thallium sulfate, 285

Tigan. 244

Warfarin, 285

WY.4036, 21

Zinc Phosphide, 15, 301

NoNCHEMICAL

Conditioned or secondary punisher, 29

Electroconvulsive shock, 21, 221, 223, $225,226,281,292$

Foot shock, 21, 146, 108, 161, 162 , 174,228

Histidine-free diet, $39,40,41,350,351$ 352

Morphine withdrawal, 295, 296

Radiation, 11, 12, 17, 45, 79, 80, 91, 101, $126,127,130,142,143,144,145,146$, $147,153,155,157,162,190,193,200$, $201,202,219,224,240,244,255,262$, $263,264,265,266,268,274,276,297$ $299,304,307,316,317,318,334,335$ $336,338,339,358,359,360,361,362$, 363, 364. 365, 371, 372, 375, 387, 389 
Rotation, 46, 51, 173, 203

Sensory preconditioned stimulus, 230

Thiamine deficiency, 252, 322, 323, 399 , 402

Tongue shock, 320

\section{Dosimetry}

$1,2,15,21,23,55,66,68,72,75,77$ $78,87,88,90,92,100,101,106,110$. $114,115,120,143,144,145,151,157$, $164,173,176,190,199,200,204,220$. $224,233,238,249,256,281,282,285$, $289,292,304,310,312,316,318,319$, $359,360,361,375,380,383,397$

\section{Acquisition \\ Conditioned Stimulus- Unconditioned Stimulus Interval \\ ContigutTr \\ $12,13,21,35,53,59,60,62,79,107$, $127,142,150,161,164,168,187,188$ $208,209,210,211,213,223,228,230$, $262,263,274,280,286,288,291,304$, $316,324,336,350,362,373,395,397$ \\ INTERFE RENCE \\ $3,4,25,28,35,59,60,62,68,96,98$, 107. 201, 204, 208, 210, 211, 212, 213, $215,222,223,224,225,226,233,234$, 239. 240, 246, 272, 281, 292, 307, 315, $317,324,329,394$}

\section{Preexposure}

CONDITIONED

Almond, $3 \%$

Amylacetate, 374

Anise, 3, 25, 252

Apple. 187, 190

Banana, 252

Black box, 29

Bright/noisy water, 146,172

Casein hydrolysate, $213,324,329$

Caterpillars, 337

Cat food. 393

Chocolate. 320

Cinnamon, 252

Cocoa, 252

Coconut, 320,395

Coffee. 99. 329, 349

Earthworms. 337

Ethanol, 23, 297, 311

Food cups, 273, 324

Glucose, 253, 294

Grape. 114. 168, 169, 170, 190, 307, 394

Lamb, 181, 184

Maple, 252, 320, 400

Mealu orms, 337

Mice. 97, 164, 291

Milk, $169,170,307,382,394$

Millet seed, 15

Morphine sulfate, 129, 276, 376

Orange. 114

Rabbit. 181. 184

Rat Chow, 155

Saccharin, 3, 16, 17, 50, 54, 59,60,62, $103,116,126,130,134,142,143,146$, $147.153,157,172,173,187,188,190$, $197,208,214,228,240,259,264,265$, $268,280,295,315,316,324,334,338$, $371,392,400$

Saccharin/glucose, 253

Sodium chloride, 91, 132, 134, 146, 147, 299. 395
Sucrose, 128, 213,283, 300, 304, 307, 329

Sucrose-octa-acetate, 296

Vanilla, 252, 320,400

Vinegar, 147, 208, 349

Visual/auditory/tactile cues, 147

Water, 16, 46, 47, 51, 73, 104, 117, 125 .

$126,145,147,150,155,157,201,202$.

204, 212, 228, 247, 256, 262, 263, 265,

266. 275, 280, 288, 311, 334, 335, 336,

$358,359,361,363,365,372,389$

Wet and dry food. 161

Unconditioned Stimulus

Alloxan monohydrate. 52. 54

Amphetamine, 51, 70, 73, 232

Apomorphine, 24

Calcium chloride, 337

Chlordiazepoxide, 73

Cyclophosphamide, 118

Delta-1-THC, 87

Electroconvulsive shock. 224

Ethanol. 23

Halothane, 329

Histidine-free load, 351

Lithium chloride, 51, 212, 224, 239, 281, $311,312,329,341,374$

Morphine sulfate, 73, 204, 232, 276, 29. 376,377

Pentobarbital, 312

Radiation, 320, 335

Rotation, 51

Scopolamine, 22, 51

Shock, 1

Trypan blue, 292

Tumbling, 389

\section{Repeated Trials}

Alloxan monohydrate, 52

Alpha-methylparatyrosine, 78

Amphetamine. 16, 68, 70, 73, 75, 76, 77 , $164,232,256,257$

Apomorphine, 24, 26, 43, 44, 147, 150. $167,168,169,170,172,198,324$

Calcium chloride, 337

Cholecystokinin. 198

Chlordiazepoxide, 72, 73

Conditioned or secondary punisher, 29

Cyclophosphamide, $110,117,123,125$, 151, 161, 176, 178

Deionized water, 55. 353

Ethanol, 23, 72, 114, 199

Formalin, 395

Glucose, 99

Hypertonic procaine, 272

Insulin, 248, 249

Isotonic procaine, 272

l-1soproterenol hydrochloride, 254

Lithium chloride, 9, 56, 63, 92, 97, 102 $105,108,128,132,133,134,146,158$, $174,181,186,187,188,197,230,234$ $259,260,272,273,275,279,285,291$ $303,311,320,341,367,369,374,378$. 396. 397

Mercuric chlonde, 220

Methylatropine, 84,382

Morphine sulfate, $72,73,204,232,233$. 296

Naloxone hydrochloride, 204, 233

Octapeptıde (cholecystokinin). 198

Oxythiamine hydrochloride. 346

Pilocarpine, 164

Radiation, 17, 91, 146, 147, 153, 155 $162,190,219,255,268,310,318,339$
Rotation, 46 173

Sensory preconditioned stimulus, 230

Seriun from irradiated animals. 152

Shock, 108, 161, 162, 320

Sodrum chloride, 100

Struchnine sulfate. 28.5

Thiamine deficiency, 322,323,399, 402

Zinc phosphate, 15, 301

\section{Constraints on Acquisition}

Conditioned stimulus specificity

Unconditioned stimulus specificity, 285

Conditioned stimulus-unconditioned stimulus specificitv. $108,146,147,161,162$. $172,228,257,387,391$

\section{Nonassociative Effects}

Sensitization (neophobia), 37, 44, 46, 47. $48,49,68,80,91,104,105,125,126$, $134,137,145,150,157,199,201,204$. $228,230,246.247,262,266,274,275$, $280,281,299.304,334,335,354,358$. $359,361,363,365$

Backward conditioning, $12,21,32,53,59$, $60,63,76,79,80,87,90,125,130,142$. $201,230,244,257,262,263,265,266$, 274, 288, 312, 316, 334, 335, 336, 359. $361,363,365,372$

\section{Extinction}

Conditioned stimulus alone, $1,2,8,9,11$ $13,15,17,18,20,3236,37,40,41,44$. $46,49,54,65,71,76,78,84,91,92,97$ $99.103,104,105,106,107,109,110$, $111,114,115,116,118,126,128,129$. $130,132,133,134,137,142,143,147$ $150,151,152,153,155,157,161,164$ $167,168,169,170,176,178,187,188$, $190,193,199,204,221,239,240,247$ $248,254,256,257,260,263,264,265$, $266,268,269,272,273,276,277,279$, $290,291,294,295,297,298,300,301$, $303,310,311,315,316,317,318,323$. $334,335,336,337,338,339,349,351$, $355,363,366,373,374,377,378,388$, $389,391,393,394,397,400,401,402$

Unconditioned stimulus alone

Retention, 30, 31, 39, 55, 60, 77, 112, 181, 200. 209

PHYSIOLOGICAL MANIPULATIONS Structure Removal

Adrenal, 8. 9, $91,92,132,133,134,144$. 355

Amygdala, 214. 259, 283

Anteromedial cortex, 1012

Anteromedial neostriatal, 102

Area postrema, 22

Fornix. 97

Frontal cortex, $101,18 \varepsilon$

Gustatory neocortex. 48

Hippocampus, 25, 259, 268, 269, 277. 278,283

Hypophysis, 144

Lateral hypothalamus, 320,341

Medral neocortex, 48

Micrencephalus, 396

Neocortex, 277

Occlusion of the nares, 315

Olfactory bulb, 101, 18\%

Ophthalectomy, 143

Parathyrotd. 134

Posterior cortex. 188 
Septum, 186, 193, 259, 260

Suprarhinal cortex, 102

Taste cortex, 188

Ventromedial hypothalamus, 167,300 , 388

\section{Stracture Stimulation}

Amygdala, 7, 215

Diencephalus, 303

Lateral hypothalamus, 10, 76, 239, 393

Medial forebrain bundle, 303

Mesencephalic reticular formation, 10

Posterior and interior cortex, 221, 223, $225,226,281,292,316,380$

Telencephalus, 303

Heart rate, 399

\section{Structure Recording}

Hippocampal theta, 56, 58

Rectal temprature, 399

\section{PHARMACOLOGICAL} INTERVENTIONS

Alcohol, 334

Alloxon monohydrate, 52, 54

Alpha-methylparatyrosine, 76,90

Amphetamine, 51, 70, 73, 232

Apomorphine, 24

Atropine sulfate, 359,361

Calcium chloride, 337

Chlordiazepoxide, $68,71,73,85$

Chloroprothixene, 317

Chlorpheniramine, 244

Cyclophosphamide, 118

Delta-1-THC, 87

Dimethyl sulfoxide, 240

d1-isoproterenol hydrochloride, 227

Ethanol, 23, 71

Ether, 201

Equithesin, 329

Formalin, 8, 9

Halothane, 329

[2-hydroxy-3-isopropylaminopropoxy]indole, 227

Hypertonic saline, 106, 229

Lithium chloride. 51, 212, 224, 239, 281 $311,312,329,341,374$

Metrazol, 4, 271

Morphine sulfate, 73, 204, 232, 276, 295 . 296, 376, 377

Myotal. 315

Naloxone hydrochloride, 204, 233

Nembutal, 317
Pentobarbital, 312

Physostigmine, 30, 31, 361

Pilocarpine, 164

Polyethylene glycol, 8, 9

Potassium chloride, 56, 59, 60, 62, 63, 95, 96,234

Proferrin, 127

Scopolamine, 135, 222

SKF 525A, 87

Tigan, 244

Trypan blue, 292

Zinc sulfate, 15, 28, 104, 187

\section{METHODOLOGY}

Age differences, 176, 209, 220, 230, 360

Deprivation vs. no deprivation, $8,84,133$, 178, 298

Diurnal effects, $8,124,331,375$

Indiviåual differences, 115,117

One- vs. two-bottle tests, $44,77,111,115$, $125,169,176,211,401$

Route of administration

Conditioned stimulus, 18, 45, 58. 103, $109,197,334$

Unconditioned stimulus, 17, 120, 238, $282,354,366$

Sex differences, $168,220,285$

\section{COMPARATIVE} Species

Cats, 219, 393

Cod, 250

Cougar, 181,184

Coyotes, 181,184

Frogs, 337

Gerbils, 301

Guinea pigs, 49, 50, 51, 209

Hamsters, 206, 401

Mice, 123, 199, 204, 219, 240, 288, 297 . 353

Monkeys, 190, 205

Quail, 391

Rats, $1,2,3,4,6,7,8,9,10,11,12,13$, $15,16,17,18,20,21,22,23,24,25,26$, $27,28,29,30,31,32,35,36,37,39,40$, $41,43,44,45,46,47,48,52,53,54,55$ $56.58,59,60,62,63,64,66,67,68$, $70,71,72,73,75,76,77,78,79,80,84$ $85,87,88,90,91,92,95,96,97,98,99$. $100,101,102,103,104,105,106,107$ $108,109,110,111,112,113,114,115$ $116,117,118,120,122,123,124,125$ $126,127,128,129,130,132,133,134$
$135,136,137,142,143,144,145,146$, $147,150,151,152,153,155,157,158$, $161,162,164,165,167,168,169,170$, $172,173,174,176,177,178,185,186$, $187,188,189,190,193,197,198,200$. 201, 202, 203, 204, 208, 210, 211, 212, $213,214,215,219,220,221,222,223$. $224,225,226,227,228.229,230,232$, $233,234,235,238,239,244,246,247$, $248,249,252.253,254,255,256,257$, $259,260,262,263,264,265,266,268$, $269,271,272,273,274,275,276,277$, $279,280,281,282,283,285,286,287$, $289,290,291,292,294,295,296,298$. $299,300,302,303,304,307,310,311$ $312,315,316,317,318,319,320,322$. $323,324,329,331,334,335,336,338$, $339,341,346,349,350,351,352,354$, $355,358,359,360,361,362,363,364$, $365,366,367,369,370,371,372,373$. $374,375,376,377,378,380,382,383$. $384,387,388,389,391,392,394,395$, $396,397,399,400,402$

Snakes, 65

\section{Prey-Predator Interactions}

$20,84,97,164,181,184,291,337$

\section{Wildlife Conservation}

$179,180,181,182,183,184$

Rodent Control

$81,82,83,121,267,293,332,333,348$. $368,385,386$

\section{GENERAL INFORMATION}

Notes, 19, 138, 179, 180, 181, 182, 345, 356

Literature Reviews, 57, 61, 69, 74, 93, $119,139,140,148,156,159,150,163$, $183,201,216,217,237,321,326,327$. $328,347,357,381$

Related articles, 38, 42, 83, 86, 94, 121 , $122,131,166,171,175,191,194,195$, $196,207,231,236,241,242,243,245$, $261,267,270,278,284,293,306,308$, $313,314,325,330,332,333,340,348$, $368,379,385,386,398,403$

Related books, 5, 14, 81, 82, 89, 192, 218, $251,344,368,390$

Theoretical reviews, 33, 34, 119, 139, 141 , $149,154,156,159,160,258,305,309$, $321,326,327,328,342,343$ 